\title{
lodine nutritional status in Brazil: a meta-analysis of all studies performed in the country pinpoints to an insufficient evaluation and heterogeneity
}

Renata de Oliveira Campos ${ }^{1,2}$, Iasmin dos Santos Barreto', Lorena Rejane de Jesus Maia', Sara Cristina Lima Rebouças' ', Taíse Lima de Oliveira Cerqueira', Clotilde Assis Oliveira ${ }^{3}$, Carlos Antônio de Souza Teles Santos ${ }^{4}$, Carlos Maurício Cardeal Mendes ${ }^{2,5}$, Leonardo Sena Gomes Teixeira ${ }^{6}$, Helton Estrela Ramos ${ }^{1,2}$

\begin{abstract}
Objectives: lodine deficiency disorder (IDD) is the result of an inadequate dietary intake of iodine, which physiological consequences are endemic goiter and thyroid dysfunction. The objective of this study was to a analyze studies that assessed the status of Brazil's population iodine nutrition and IDD prevalence. Materials and methods: Systematic review using PRISMA statement. Electronic database: PubMed, Medline, SciELO and Lilacs. Quality of studies: Newcastle-Ottawa Scale. Metaanalysis was carried out with R Core Team Statistical Software, version 3.1.0 (2014). The summary measure (WMD) and its confidence interval $(\mathrm{Cl})$ of $95 \%$ were calculated. The "Funnel plot" graph assessed publication bias and heterogeneity. Results: Seventeen papers were eligible: pregnant women (2), school children (9), adults/elderly (4) and preschool children/infants (2). Geographic distribution: North (1), Northeast (1), Midwest (2), Southeast (13), South (3). Twenty-three thousand two hundred seventy-two subjects were evaluated between 1997 and 2013 and all have use urinary iodine (UI) measurement. However, only 7 studies could be included in meta-analysis, all from Southeast region. The overall prevalence of IDD in school children in southeast region was $15.3 \%(95 \% \mathrm{Cl}, 13-35 \%)$, however this data had an important heterogeneity, expressed by the ${ }^{2}$ Statistic of $99.5 \%$. Conclusion: Only few studies have been performed and enrolled populations from south/southeast region of Brazil. The actual IDD prevalence analysis is complex because it was detected bias due influence of individual studies and very high heterogeneity. IDD might still be high in some areas but this remained unknown even after this meta-analysis evaluation. The generation of a national program for analysis of iodine status in all regions is urgently required. Arch Endocrinol Metab. 2015;59(1):13-22
\end{abstract}

Keywords

lodine; hypothyroidism; iodine deficiency, Brazil

\author{
Department of Bioregulation, \\ Health \& Science Institute, \\ Universidade Federal da Bahia \\ (UFBA), Salvador, BA, Brazil \\ ${ }^{2}$ Post-graduate Program in \\ Interactive Processes of Organs \\ and Systems, Health \& Science \\ Institute, UFBA, Salvador, BA, Brazil \\ ${ }^{3}$ Health \& Science Center, \\ Universidade Federal do \\ Recôncavo da Bahia (UFRB), Santo \\ Antonio de Jesus, BA, Brazil \\ ${ }^{4}$ Department of Statistics, \\ Universidade Estadual de \\ Feira de Santana (UEFS), Feira \\ de Santana, BA, Brazil \\ ${ }^{5}$ Department of Biofunction, \\ Health \& Science Institute, \\ UFBA, Salvador, BA, Brazil \\ ${ }^{6}$ Institute of Chemistry, \\ UFBA, Salvador, BA, Brazil \\ Correspondence to: \\ Helton Estrela Ramos \\ Departamento de Biorregulação, \\ Universidade Federal da Bahia \\ Av. Reitor Miguel Calmon, s/n, \\ sala 300 \\ 40110-100 - Salvador, BA, Brazil \\ ramoshelton@gmail.com
}

Received on Sept/3/2014 Accepted on Oct/12/2014

DOI: 10.1590/2359-3997000000004

\section{INTRODUCTION}

$\mathrm{I}$ odine is an essential micronutrient for the synthesis of thyroid hormones (TH), which are important for homeostasis and neurodevelopment (1-5). The World Health Organization (WHO) recomends daily iodine intake of $50 \mu \mathrm{g}$ for newborns, $90 \mu \mathrm{g}$ for children between 13 months and 6 years, $120 \mu \mathrm{g}$ for children (7-12 years), $150 \mu \mathrm{g}$ for adults (after 12 years) and $250 \mu \mathrm{g}$ for pregnant and lactating women (6-7). Iodine deficiency disorder (IDD) is the result of an inadequate dietary intake of iodine, whose physiological consequence is an abnormal function of the thyroid gland, hypothy- roidism and endemic goiter (8). The harmful effects of IDD are even more severe in pregnant women, fetuses and children, being the worldwide most common cause of preventable mental retardation (6,7,9-11).

The Brazilian Government have been controlling salt iodization in the country, according to Federal Law 6,150, in partnership with the National Agency for Sanitary Surveillance (Anvisa) and the salt productive sector (12-14). In accordance with Resolution RDC $\mathrm{n}^{\mathrm{o}} 130$ (2003), it was deemed fit, for human consumption, salt content that corresponded to $20-60 \mathrm{ppm}$ of iodine concentration and this recommendation have 
been prevailed for ten years (14). However, in the mean time, data from the ThyroMobil Project in Latin America, identified Brazil (with 17 sentinel sites and a total of 1,563 school children evaluated) as a country of excessive iodine consumption, with a mean urinary iodine excretion (UIE) concentration of $360 \mu \mathrm{g} / \mathrm{L}(15,16)$. Consequently, the levels of salt iodization were recently reduced to 15 to 45 milligrams of iodine per kilogram of product (http://www.in.gov.br) (17). Notwithstanding, the Brazilian Endocrine Society (SBEM) have strongly diverged on this reduction (http://www.tireoide.org.br/reducao-de-iodo-no-sal/).

The fact is that there is not recent national survey study about iodine content in table salt in households from different regions of Brazil neither a continuous monitoring of the overall population iodine status. Therefore, given the above, this review aimed to systematize and analyze all studies which assessed the prevalence of IDD in Brazil through UIE analysis in order to describe the current available information about iodine nutrition status.

\section{MATERIALS AND METHODS}

\section{Research questions}

(1) What is the overall prevalence of IDD in Brazil?; (2) What is the prevalence of IDD in different areas and population groups?; (3) Are there enough studies to profile the population iodine nutrition status?; (4) Are there differences related to IDD in individuals of distinct ages, from one region to another, or in separate areas of the same region?; (5) Are the published data prevailing and have comprised all regions of Brazil?.

\section{Search strategy and data collection}

This systematic review is reported in accordance with the PRISMA (preferred reporting items for systematic reviews and meta-analyses) statement $(18,19)$. Analysis of all studies conducted in Brazil in order to assess the status of iodine nutrition in populations - retrieved from the electronic database PubMed, Medline, SciELO and Lilacs. We have not limited the period of the study because we wanted to reach all studies conducted in the country. The search strategy used controlled vocabulary supplemented with keywords describing the following concepts, not only limited to English language publications, in the form of: "Iodine" and "Brazil" and "Iodine deficiency" and "Brazil" and "Thyroid function tests" and "Brazil". Unpublished studies were also investigated in the largest thesis and doctoral dissertations database of a Brazilian Agency (Capes). The searching by hand has been conducted in the references of the review papers and in a few non-indexed Medline Brazilian journals. Duplicate publication was checked and, if necessary, the corresponding author was contacted. After this, reviews of iodine status methods were collected in full text, the reference lists were checked and the included study list was updated accordingly.

\section{Quality assessment}

Two reviewers working independently (R.O.C. and H.E.R.) assessed the methodological quality of included observational studies using the Newcastle-Ottawa Scale and adapted Newcastle-Ottawa Scale to evaluate cross sectional studies (20). This instrument assesses the protection against bias due subject selection methodology, evaluation and data analysis.

\section{Study selection}

Inclusion criteria were defined as follow: a) the language in which the article was published was English or Portuguese; b) the main purpose of the article: assessment of iodine nutritional status of individuals; $c$ ) primary studies conducted in Brazil; and d) description of percentage of IDD, sufficiency and excess iodine, according to the criteria established by WHO. Experimental animal studies, review articles, case reports, studies investigating iodine nutrition in individuals with thyroid disorders or chronic diseases, studies on the iodine nutritional and duplicate articles in the databases were excluded.

\section{Diagnosis of iodine deficiency disorders}

The WHO recommendations regarding IDD assessment have been followed by the selected studies. UIE was measured using different methods and in a number of different units that could not always be interconverted to allow comparison between studies (Table 1). The studies selected for the meta-analysis had UIE generally, UIE was determined by the colorimetric ceric arsenite method based on the Sandell-Kolthoff (S-K) reaction, previously considered as the gold standard (21). Normal reference range was considered 100-299 $\mu \mathrm{g} / \mathrm{l}$ for general population and 150-499 $\mu \mathrm{g} / \mathrm{l}$ for pregnant woman, according to $\mathrm{WHO}(8,9)$. 
Table 1. Summary from studies conducted in Brazil in the between 1985-2013

\begin{tabular}{|c|c|c|c|c|c|}
\hline Study & Population & Methodology & Outcomes & $\begin{array}{l}\text { Study } \\
\text { Quality }\end{array}$ & Conclusions \\
\hline $\begin{array}{l}\text { Alves and cols. (22) } \\
\text { Cross-sectional study } \\
\text { Year of study: 1985-1990 } \\
\text { Year of publication: } 2005\end{array}$ & $\begin{array}{l}\text { 15,131 newborns } \\
\text { 7,797 males, } 7,328 \text { females } \\
\text { Location: Ribeirão Preto, SP }\end{array}$ & $\begin{array}{l}\text { Umbilical cord blood for TSH } \\
\text { and T4 dosage } \\
\text { UIE sample } 24 \text { hours (S-K } \\
\text { reaction) in } 141 \text { newborns }\end{array}$ & $\begin{array}{l}1 / 141 \text { infants had TSH level } \\
\text { equal to } 19.4 \mu \mathrm{lU} / \mathrm{mL} \text {. The UI } \\
\text { ranged between } 2.1 \text { and } \\
194 \mu \mathrm{g} / \mathrm{L}\end{array}$ & 5 & $\begin{array}{l}\text { Newborns were subjected } \\
\text { to borderline IDD }\end{array}$ \\
\hline $\begin{array}{l}\text { Correa Filho and cols. (23) } \\
\text { Cross-sectional study } \\
\text { Year of study: } \\
\text { 1994-1996 } \\
\text { Year of publication: } 2002\end{array}$ & $\begin{array}{l}\text { 178,774 schoolchildren } \\
\text { aged 6-14 years } \\
\text { Location: } 428 \text { cities of all } \\
\text { Brazilian states }\end{array}$ & $\begin{array}{l}\text { UIE and table salt evaluation } \\
\text { Palpation for goiter } \\
\text { assessment }\end{array}$ & $\begin{array}{l}7,702 / 16,803 \text { were } \\
\text { evaluated of urine samples } \\
\text { collected for Ul } \\
\text { measurement. The median } \\
\text { UI level was } 14.0 \mu \mathrm{g} / \mathrm{dL} \text {. The } \\
\text { median Ul level for the } \\
\text { population in the states of } \\
\text { AC, AM, and TO was equal } \\
\text { to or below } 9.0 \mu \mathrm{g} / \mathrm{dL}\end{array}$ & 6 & $\begin{array}{l}33 \% \text { of schoolchildren had } \\
\text { some degree of IDD and in } \\
12 \% \text {, UIE levels were less } \\
\text { than } 5 \mu \mathrm{g} / \mathrm{dL} \text {, characterized } \\
\text { severe deficiency }\end{array}$ \\
\hline $\begin{array}{l}\text { Esteves (24) } \\
\text { Cross-sectional study } \\
\text { Year of study: } 1996 \\
\text { Year of publication: } 1997\end{array}$ & $\begin{array}{l}16,803 \text { schoolchildren aged } \\
6-14 \text { years, both sexes } \\
\text { Location: schods publics of } \\
401 \text { cities in all Brazilian } \\
\text { states }\end{array}$ & UIE (adapted S-K method) & $\begin{array}{l}\text { We observed IDD in } 85 \\
\text { cities, moderate DDI ( } \geq 25 \\
\text { and }<50 \mu \mathrm{g} / \mathrm{L} \text { ) in Cocos in } \\
\text { Bahia, and Almas, Arraias } \\
\text { and Paraná in Tocantins, and } \\
\text { to mild (values } \geq 50 \text { and }< \\
100 \mu \mathrm{g} / \mathrm{L}) \text {. In the other } 35 \\
\text { counties, median values } \\
\text { were normal, but more than } \\
10 \% \text { of children had urine } \\
\text { iodine levels below } 25 \mu \mathrm{g} / \mathrm{L}\end{array}$ & 4 & $\begin{array}{l}\text { Mild to moderate IDD in } \\
30 \% \text { of the cities }\end{array}$ \\
\hline $\begin{array}{l}\text { Barca and cols. (25) } \\
\text { Cohort } \\
\text { Year of study: } 1998\end{array}$ & $\begin{array}{l}800 \text { pregnant women. } 386 \\
\text { puerperal healthy women } \\
\text { was followed-up regularly at } \\
3.6 .12 \text { and } 24 \text { months }\end{array}$ & $\begin{array}{l}\text { TSH, FT4, Tg, anti-Tg and } \\
\text { anti-TPO antibodies. } \\
\text { Thyroid ultrasound }\end{array}$ & $\begin{array}{l}\text { The median Ul excretion was } \\
167.8 \mu \mathrm{g} / \mathrm{L}\end{array}$ & 7 & $\begin{array}{l}\text { Adequate iodine nutritional } \\
\text { status. No correlation with } \\
\text { TPP }\end{array}$ \\
\hline
\end{tabular}

Year of publication: 2001

Nimer and cols. (26)

Cross-sectional study

Year of study: 1996

Year of publication: 2002

Pretell and cols. (16)

Cross-sectional study

Year of study: 1998-2000

Year of publication: 2004

\section{Saab (27)}

Cross-sectional study

Year of study: 1998-2000

Year of publication: 2000

Marino and cols. .* (28)

Year of study: 2002-2003

Year of publication: 2009

\section{Duarte (29)}

Cross-sectional study

Year of study: 2003-2007

Year of publication: 2007
$3,6,12$ and 24 months

Location: public hospital in Sao Paulo, SP

280 schoolchildren
Location: two elementary
schools, one private and one
public of Ouro Preto, Minas
Gerais

\section{1,563 schoolchildren}

Location: 17 sentinel sites

distributed in 8 states (PA,

MA, TO, GO, MT, MS, MG and $\mathrm{ES}^{*}$ )

1,000 school children
Location: Mato Grosso do
Sul

13 adults aged 22-63 years Location: city of Santo André, SP

964 school children
Location: public schools in
six cities in Sao Paulo
(Taubaté, Registro, Ribeirão
Preto, São José do Rio Preto,
Araçatuba, Presidente
Prudente)

UIE (S-K reaction)

\section{UIE (adapted S-K. method) \\ Measure levels iodine of salt \\ The concentration levels of UI were normal in $92.2 \%$ of private school students and $42.6 \%$ of public school children}

UIE by Pino and cols. method (26)

Table salt

Thyroid ultrasounds

UIE (S-K reaction). TSH and FT4, Tg, anti-Tg and anti-TPO antibodies

Assessment of goiter by palpation

Thyroid ultrasound

T3, T4, FT4, TSH, A-Tg,

A-TPO, TSHR.

UIE (S-K reaction)

Thyroid ultrasound

UIE (S-K method modified)
UIE was $<50 \mu \mathrm{g} / \mathrm{L}$ in $2.3 \%$, $70.6 \%$ with $\mathrm{UI}>300 \mu \mathrm{g} / \mathrm{L}$. The median UI concentrations of $360 \mu \mathrm{g} / \mathrm{L}$

Had Ul lower than $50 \mu \mathrm{g} / \mathrm{dL}$. The total number of samples with values below UI $5 \mu \mathrm{g} / \mathrm{dL}$. In $95.2 \% \mathrm{UI}>10 \mu \mathrm{g} / \mathrm{dL}$, $22.1 \%>30 \mu \mathrm{g} / \mathrm{dL}$

2 subjects with deficiency ( $60 \mu \mathrm{g} / \mathrm{L}$ and $66 \mu \mathrm{g} / \mathrm{L}), 5$ with excess (360-490 $\mu \mathrm{g} / \mathrm{L})$, 6 subjects with adequate UIE (150-295 $\mu \mathrm{g} / \mathrm{L})$

UIE was $<100 \mu \mathrm{g} / \mathrm{L}$ in

$1.5 \%, 21.6 \%$ of $100-299$

and $76.7 \%$ with UIE $>300$ $\mu \mathrm{g} / \mathrm{L}$ $29.1 \%$ of $200-299 \mu \mathrm{g} / \mathrm{L}$ and
$4 \quad$ lodine status was drastically different between private and public school students

$7 \quad$ lodine excess was more prevalent

$6 \quad$ Goiter prevalence was low. UIE was above the recommended iodine content in salt was adequate

7 lodine adequate sufficiency with an UIE mean of 262.31 $\mu g / L$

6 Excessive iodine intake in students from Sao Paulo 


\begin{tabular}{|c|c|c|c|c|c|}
\hline Study & Population & Methodology & Outcomes & $\begin{array}{l}\text { Study } \\
\text { Quality }\end{array}$ & Conclusions \\
\hline $\begin{array}{l}\text { Soares and cols. (30) } \\
\text { Cross-sectional study } \\
\text { Year of study: 2003-2005 } \\
\text { Year of publication: } 2008\end{array}$ & $\begin{array}{l}147 \text { pregnant women } \\
\text { Location: Public health care } \\
\text { clinics of Porto Alegre, Rio } \\
\text { Grande do Sul }\end{array}$ & $\begin{array}{l}\text { Measurement of UIE (S-K } \\
\text { reaction) and creatinina } \\
\text { Thyroid ultrasound } \\
\text { FT4 and Tg }\end{array}$ & $\begin{array}{l}\text { Mean UI was } 226 \pm 87 \mu \mathrm{g} / \mathrm{L} \\
\text { and median Ul was } 224 \\
\mu \mathrm{g} / \mathrm{L} \text {. UIE levels ranged from } \\
22 \mu \mathrm{g} / \mathrm{L} \text { to } 534 \mu \mathrm{g} / \mathrm{L} \text {. } \\
\text { Twenty-nine women (19.6\%) } \\
\text { had Ul below } 150 \mu \mathrm{g} / \mathrm{L}\end{array}$ & 6 & $\begin{array}{l}19.7 \% \text { had insufficient } \\
\text { iodine intake. No correlation } \\
\text { between serum FT4, Tg and } \\
\text { TV with UIE }\end{array}$ \\
\hline $\begin{array}{l}\text { Navarro and cols. (31) } \\
\text { Cross-sectional study } \\
\text { Year of study: } 2004 \\
\text { Year of publication: } 2010\end{array}$ & $\begin{array}{l}145 \text { schoolchildren, } 79 \text { from } \\
\text { rural areas and } 66 \text { from } \\
\text { urban area } \\
\text { Location: Botucatu, Sao } \\
\text { Paulo }\end{array}$ & $\begin{array}{l}\text { UIE (S-K reaction) and table } \\
\text { salt }\end{array}$ & $\begin{array}{l}\text { IDD was detected in 3,4\% } \\
\text { and } 3 \% \text { of children from the } \\
\text { rural and urban school, } \\
\text { respectively. Ul greater then } \\
300 \mu \mathrm{g} / \mathrm{L} \text { was detected in } \\
62,3 \% \text { and } 90,9 \% \text { of } \\
\text { students from the rural and } \\
\text { urban school, respectively }\end{array}$ & 6 & $\begin{array}{l}\text { IDD is controlled in school } \\
\text { children, with high } \\
\text { prevalence of UIE excess }\end{array}$ \\
\hline $\begin{array}{l}\text { Camargo and cols. (32) } \\
\text { Cross-sectional study } \\
\text { Year of study: } 2004 \\
\text { Year of publication: } 2008\end{array}$ & $\begin{array}{l}1,085 \text { individuals aged } \\
20-87 \text { years } \\
\text { Location: metropolitan area } \\
\text { in Sao Paulo (houses } \\
\text { randomly selected) }\end{array}$ & $\begin{array}{l}\text { UIE (S-K method) and table } \\
\text { salt } \\
\text { Thyroid ultrasound } \\
\text { TSH, TPOAb }\end{array}$ & $\begin{array}{l}\text { UIE } \geq 300 \text { in } 45.6 \%, 14.1 \% \\
\text { had UIE greater than } 400 \text {. } \\
\text { The prevalence of CAT was } \\
16,9 \%\end{array}$ & 8 & $\begin{array}{l}\text { High prevalence of iodine } \\
\text { excess and CAT }\end{array}$ \\
\hline $\begin{array}{l}\text { Carvalho and cols. (33) } \\
\text { Cross-sectional study } \\
\text { Year of study: } 2004 \text { to } 2007 \\
\text { Year of publication: } 2012\end{array}$ & $\begin{array}{l}828 \text { schoolchildren } \\
\text { Location: Botucatu, Sao } \\
\text { Paulo }\end{array}$ & $\begin{array}{l}\text { Determination of UIE casual } \\
\text { urine sample (adapted S-K } \\
\text { method) }\end{array}$ & $\begin{array}{l}\text { Only } 1.9 \% \text { had low values of } \\
\text { urinary iodine }(100 \mu \mathrm{g} / \mathrm{L}) \text {, } \\
\text { while } 24.6 \% \text { had Ul excretion } \\
\text { values between } 200 \text { and } 300 \\
\mu \mathrm{g} / \mathrm{L} \text {, and } 67.1 \% \text { had values } \\
\text { above } 300 \mu \mathrm{g} / \mathrm{L}\end{array}$ & 6 & $\begin{array}{l}\text { High excessive iodine intake } \\
\text { rate in school children }\end{array}$ \\
\hline $\begin{array}{l}\text { Vanacor and cols. (34) } \\
\text { Cross-sectional study } \\
\text { Year of study: 2005-2007 } \\
\text { Year of publication: } 2008\end{array}$ & $\begin{array}{l}60 \text { subjects } \\
\text { Location: Hospital de } \\
\text { Clínicas de Porto Alegre, Rio } \\
\text { Grande do Sul }\end{array}$ & $\begin{array}{l}\text { Four urine samples from } \\
\text { each participant (completing } \\
24 \mathrm{~h}-\mathrm{UIE} \text { ) } \\
\text { Dietary history } \\
\text { UIE, creatine (Cr) and } \mathrm{Na}+ \\
\text { levels were measured in the } \\
4 \text { partial urine samples and } \\
\text { in the } 24 \mathrm{~h} \text { urine sample }\end{array}$ & $\begin{array}{l}\text { The UIE and sodium } \\
\text { excretions were variable } \\
\text { along the } 24 \text {-hour period. } \\
\text { The correlation between the } \\
\text { total iodine and sodium } \\
\text { excretions was very strong }\end{array}$ & 4 & $\begin{array}{l}\text { The UIE is variable during the } \\
\text { daytime. Between lunch and } \\
\text { dinner, it seems to better } \\
\text { reflect the } 24 \text {-hour Ul. The } \\
\text { casual urine sample collection } \\
\text { in this period would probably } \\
\text { be the best for the iodine } \\
\text { nutritional status evaluation }\end{array}$ \\
\hline $\begin{array}{l}\text { Pontes and Adan (35) } \\
\text { Cross-sectional study } \\
\text { Year of study: not described } \\
\text { Year of publication: } 2006\end{array}$ & $\begin{array}{l}180 \text { schoolchildren } \\
\text { Location: public schools } \\
\text { from Cabaceiras, Paraíba }\end{array}$ & $\begin{array}{l}\text { Questionnaire nutritional } \\
\text { UIE (Rapid Urinary lodine } \\
\text { Test }^{\circledR} \text { ) }\end{array}$ & $\begin{array}{l}31.6 \% \text { of scholars used } \\
\text { cassava in their meals with a } \\
\text { frequency larger than three } \\
\text { times a week. } 33.3 \% \text { scholars } \\
\text { presented UIE } \leq 100 \mu \mathrm{g} / \mathrm{L}\end{array}$ & 2 & $\begin{array}{l}\text { Goitrogenic foods are } \\
\text { higerly consumed. One third } \\
\text { of school children had low } \\
\text { Ul levels less than } 100 \mu \mathrm{g} / \mathrm{L}\end{array}$ \\
\hline $\begin{array}{l}\text { Alves and cols. (36) } \\
\text { Cross-sectional study } \\
\text { Year of study: 2007-2008 } \\
\text { Year of publication: } 2010\end{array}$ & $\begin{array}{l}300 \text { schoolchildren } \\
\text { Location: public schools of } \\
\text { different socioeconomic } \\
\text { levels from Ribeirão Preto, } \\
\text { Sao Paulo }\end{array}$ & $\begin{array}{l}\text { UIE (S-K reaction) and table } \\
\text { salt } \\
\text { Thyroid ultrasound }\end{array}$ & $\begin{array}{l}100 \% \text { of the urine samples } \\
\text { had Ul values greater than } \\
100 \mu \mathrm{g} / \mathrm{L}, 59.5 \% \text { of subjects } \\
\text { had values above } 300 \mu \mathrm{g} / \mathrm{L}\end{array}$ & 5 & $\begin{array}{l}\text { lodine sufficiency in } \\
\text { Ribeirão Preto school } \\
\text { children population. UIE } \\
\text { showed excess in 59,5\% }\end{array}$ \\
\hline $\begin{array}{l}\text { Macedo and cols. (37) } \\
\text { Cross-sectional study } \\
\text { Year of study: } 2008 \\
\text { Year of publication: } 2012\end{array}$ & $\begin{array}{l}475 \text { children } \\
\text { Location: Novo Cruzeiro, } \\
\text { Minas Gerais }\end{array}$ & $\begin{array}{l}\text { UIE (S-K reaction) and table } \\
\text { salt }\end{array}$ & $\begin{array}{l}\text { IDD prevalence was } 34.4 \% \text {, } \\
23.5 \% \text { (mild), } 5.9 \text { (moderate) } \\
\text { and } 5 \% \text { (severe) }\end{array}$ & 7 & IDD prevalence of $34,4 \%$ \\
\hline $\begin{array}{l}\text { Macedo (38) } \\
\text { Cross-sectional study } \\
\text { Year of study: } 2008 \\
\text { Year of publication: } 2010\end{array}$ & $\begin{array}{l}540 \text { school children } \\
\text { Location: Novo Cruzeiro, } \\
\text { Minas Gerais }\end{array}$ & $\begin{array}{l}\text { UIE (S-K method) and table } \\
\text { salt }\end{array}$ & $\begin{array}{l}\text { IDD prevalence was } 38.9 \% \\
\text { ( } 28.7 \% \text { mild, } 6.2 \% \\
\text { moderate and } 4 \% \text { severe) }\end{array}$ & 8 & $\begin{array}{l}\text { High rate of IDD of } 38,9 \% \text {. } \\
\text { Need to evaluated control } \\
\text { as disease }\end{array}$ \\
\hline $\begin{array}{l}\text { Milhoransa and cols. (39). } \\
\text { Cross-sectional study } \\
\text { Year of study: } 2009 \\
\text { Year of publication: } 2010\end{array}$ & $\begin{array}{l}47 \text { healthy individuals, } 22 \\
\text { men and } 25 \text { women, aged } \\
18 \text { years or older } \\
\text { Location: Hospital de } \\
\text { Clínicas de Porto Alegre, Rio } \\
\text { Grande do Sul }\end{array}$ & $\begin{array}{l}\text { UIE in } 24 \mathrm{~h} \text { samples (S-K } \\
\text { reaction) } \\
\text { Evaluation of the content of } \\
\text { creatinine, sodium, and } 18 \\
\text { subjects with one, } 15 \text { with } \\
\text { two, and } 14 \text { with three } \\
\text { collections of urine } \\
\text { samples/24h }\end{array}$ & $\begin{array}{l}\text { 2/14 women had } 24-\mathrm{h} \text { UIE } \\
\text { below } 138 \mu \mathrm{g} / 24 \mathrm{~h} \text { in the } \\
\text { three samples studied }\end{array}$ & 6 & $\begin{array}{l}\text { UIE is adequate in the } \\
\text { group of } 14 \text { people, } \\
\text { however, the UIE two } \\
\text { women suggests IDD }\end{array}$ \\
\hline
\end{tabular}




\begin{tabular}{|c|c|c|c|c|c|}
\hline Study & Population & Methodology & Outcomes & $\begin{array}{c}\text { Study } \\
\text { Quality }\end{array}$ & Conclusions \\
\hline $\begin{array}{l}\text { Lima and cols. (40) } \\
\text { Cross-sectional study } \\
\text { Year of study: } 2009 \\
\text { Year of publication: } 2013\end{array}$ & $\begin{array}{l}33 \text { infants (less than } 6 \\
\text { months of age) and their } \\
\text { mothers. } \\
\text { Location: Guariba, Sao } \\
\text { Paulo. }\end{array}$ & $\begin{array}{l}\text { UIE and levels in the urine } \\
\text { and maternal milk were } \\
\text { assessed by ICP-MS } \\
\text { Table salt }\end{array}$ & $\begin{array}{l}\text { The median UIE value in the } \\
\text { infants was } 293 \mu \mathrm{gg} / \mathrm{L} \text {; the } \\
\text { mean iodine concentration } \\
\text { was } 206 \mu \mathrm{g} / \mathrm{L} \text { in the } \\
\text { maternal milk and } 39.9 \mathrm{mg} \\
\mathrm{l} / \mathrm{kg} \text { in the salt }\end{array}$ & 3 & $\begin{array}{l}\text { The median infant UIE was } \\
\text { elevated due to the high } \\
\text { iodine concentration present } \\
\text { in the maternal milk. High } \\
\text { iodine values were caused } \\
\text { by high salt iodine levels, } \\
\text { which should be reduced }\end{array}$ \\
\hline $\begin{array}{l}\text { Rates (41) } \\
\text { Cross-sectional study } \\
\text { Year of study: } 2009 \\
\text { Year of publication: } 2010\end{array}$ & $\begin{array}{l}428 \text { schoolchildren aged } 10- \\
19 \text { years }(63.3 \% \text { female and } \\
36.7 \%) \\
\text { Location: public schools of } \\
\text { Vespasian, Minas Gerais }\end{array}$ & $\begin{array}{l}\text { Anthropometry. } \\
\text { UIE (S-K reaction) }\end{array}$ & $\begin{array}{l}\text { 4.4\% with IDD, } 28.7 \% \text { with } \\
\text { appropriate indices, } 46.7 \% \\
\text { more than adequate and } \\
20.1 \% \text { excessive }\end{array}$ & 6 & $\begin{array}{l}\text { The excessive } \\
\text { concentrations of iodine in } \\
\text { the urine were associated } \\
\text { with female gender, } \\
\text { adequate percentage of } \\
\text { iodine in salt and } \\
\text { overweight or obesity }\end{array}$ \\
\hline $\begin{array}{l}\text { Almeida (42) } \\
\text { Cross-sectional study } \\
\text { Year of study: 2011- } 2012 \\
\text { Year of publication: } 2013\end{array}$ & $\begin{array}{l}125 \text { newborns } \\
\text { Location: Hospital } \\
\text { Universitário Cassiano } \\
\text { Antônio Moraes, } \\
\text { Universidade Federal do } \\
\text { Espírito Santo, Vitoria, ES }\end{array}$ & $\begin{array}{l}\text { UIE (S-K reaction) } \\
\text { TSH, FT4, Tg, anti-TPO, } \\
\text { anti-TG and anti-TSH } \\
\text { receptor (TRAb) }\end{array}$ & $\begin{array}{l}\text { The average TSH was } 1.74 \text {. } \\
\text { The average FT4 was } 1.99 \\
\mathrm{ng} / \mathrm{mL}\end{array}$ & 6 & $\begin{array}{l}\text { All } 125 \text { neonates were } \\
\text { euthyroid and had normal } \\
\text { UIE }\end{array}$ \\
\hline $\begin{array}{l}\text { Ferreira (43) } \\
\text { Case-control study } \\
\text { Year of study: 2008-2009 } \\
\text { Year of publication: } 2011\end{array}$ & $\begin{array}{l}191 \text { pregnant women aged } \\
18 \text { years and gestational age } \\
\text { up to } 14 \text { weeks } \\
\text { Location: Health Center } \\
\text { Street School Cuiabá and } \\
\text { School Health Center of } \\
\text { Avenida Dom Pedro, Ribeirão } \\
\text { Preto, Sao Paulo }\end{array}$ & $\begin{array}{l}\text { UIE (S-K reaction) } \\
\text { TSH, FT4 and total T4 }\end{array}$ & $\begin{array}{l}19(9.9 \%) \text { pregnant women } \\
\text { had UIE > } 250 \mu \mathrm{g} / \mathrm{L}, 63 \\
(33 \%) \text { had UIE in the normal } \\
\text { range }(150-250 \mu \mathrm{g} / \mathrm{L}), \text { and } \\
109(57.1 \%) \text { had UIE }<150 \\
\mu \mathrm{g} / \mathrm{L}\end{array}$ & 6 & $\begin{array}{l}\text { IDD was detected in } \\
\text { pregnant women, indicating } \\
\text { the need for iodine } \\
\text { replacement during } \\
\text { prenatal period }\end{array}$ \\
\hline
\end{tabular}

*Additional data from Rossi and cols. 2001 (44).

${ }^{* \star}$ We included only control patients results.

Quality score: 0-3 points (low quality), 4-6 points (appropriate quality), 7-9 points (high quality).

CAT: chronic autoimmune thyroiditis; ICP-MS: inductively coupled plasma mass spectrometry; IDD: iodine deficiency disorders; S-K: Sandell-Kolthoff; Ul: urinary iodine; UIE: urinary iodine excretion; TG: thyroglobulin; TSH: thyroid-stimulating hormone; TV: thyroid volume.

\section{Statistical analysis}

Statistical analyzes were performed using the R Core Team Statistical Software, version 3.1.0 (2014). The summary measure - weighted mean difference (WMD) - and its confidence interval (CI) of $95 \%$ were calculated. The heterogeneity was assessed initially through a hypothesis test for homogeneity, using the Cochran Q test (at a significance level of 5\%), and subsequent application of the $\mathrm{I}^{2}$ Statistic and visual inspection of each "Forest plot". We have determined fixed and random model effects, but was systematically employed in cases where the $\mathrm{I}^{2}$ Statistic found significant heterogeneity. As the available published data have been predominantly described in school children group, most of our data were achieved using this group. As we noted that only few studies could be selected for this investigation and the heterogeneity measured by the graph "Funnel plot" pointed to a possible publication bias, we decided to establish a cutoff of $15.3 \%$ (prevalence of overall meta-analysis) in WMD to independently calculate the IDD prevalence.

\section{RESULTS}

\section{Studies characteristics}

In our investigation, a total of 1,252 records were identified (Figure 1). We have found only 24 studies published between 1997 and 2013 eligible for this systematic review (16,22-44) (Table 1). A total of 26,148 subjects were subscribed for UIE assessment between 1997 and 2013. The most widely carried out type of study was cross-section $(\mathrm{n}=20)(86,9 \%)$. Two followup (cohort) and one case control study were also enclosed. The school environment was the place where the largest amount of data collection was performed, representing 13 studies $(56,5 \%)$.

Seventeen/twenty-three studies received adequate qualification, by Prisma analysis, for quantitative synthesis (Tables 2 and 3): pregnant women $(n=2)$, school children $(n=9)$, adults/elderly $(n=4)$ and preschool children and/or infants $(n=2)$. The country distribution was very variable, with a clear shifting toward 
southeast region: North $(\mathrm{n}=1)$, Northeast $(\mathrm{n}=1)$, Midwest $(\mathrm{n}=2)$, Southeast $(\mathrm{n}=13)$ and South $(\mathrm{n}=3)$ (Tables 2 and 3 ). Considering only the selected studies, 23,272 individuals had UIE being investigated. The main reasons for study exclusion were: incomplete or repeated results $(\mathrm{n}=5)$, gold standard methodology for UIE measurement $(\mathrm{S}-\mathrm{K})(\mathrm{n}=2)$ and data that could not be compared because absence of similar evaluation coming from others studies (10).

\section{IDD prevalence in Southeast Brazil}

The studies were subgrouped according to the region and population group (school and/or preschool children, adults, elderly and pregnant women). The overall meta-analysis performed could include only 7 studies from the Southeast region (Figure 2) the others subgroups could be not be analyzed by meta-analysis methodology. However, a high heterogeneity was immediately identified among the studies used for this meta-analysis $\left(\mathrm{p}<0.0001, \mathrm{I}^{2}=99.5 \%\right)$ (Figure 2). After applying the $\mathrm{I}^{2}$ statistic and plot Forest visual inspection, it was noted that the studies should be analyzed separately because the large heterogeneity between then. The criteria for this separation was achieved by
WMD random effect method calculation. Thus, the studies were divided by WMD average value less than $15.3 \%$ (Figure 3 ) showing IDD prevalence of $24 \%$ (95\% CI, $13-35 \%)$; and higher than $15.3 \%$ showing IDD prevalence of 32\% (95\% CI, 25-39\%) (Figure 3).

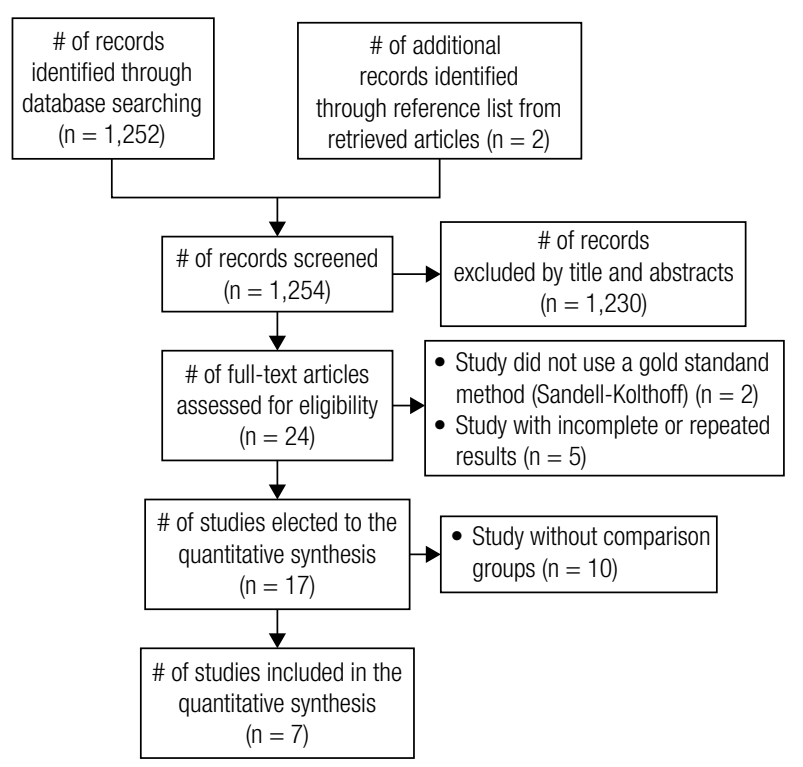

Figure 1. Study selection process.

Table 2. Urinary iodine excretion in Brazilian population

\begin{tabular}{|c|c|c|c|c|c|c|}
\hline \multirow{2}{*}{ Study } & \multirow{2}{*}{ Year } & \multirow{2}{*}{ No of subjects } & \multirow{2}{*}{ Region } & \multirow{2}{*}{ Subgroup } & \multirow{2}{*}{$\begin{array}{c}\text { Insufficient intake } \\
<100 \mu \mathrm{g} / \mathrm{L}\end{array}$} & \multirow{2}{*}{$\begin{array}{c}\text { Sufficient intake } \\
\geq 100 \mu \mathrm{g} / \mathrm{L}\end{array}$} \\
\hline & & & & & & \\
\hline \multirow[t]{5}{*}{ Esteves } & 1997 & 4,231 & North & School children & 1,985 & 2,246 \\
\hline & & 6,553 & Northeast & & 2,034 & 4,519 \\
\hline & & 2,186 & Midwest & & 748 & 1,438 \\
\hline & & 2,165 & Southeast & & 671 & 1,494 \\
\hline & & 1,668 & South & & 468 & 1,200 \\
\hline Saab & 2000 & 1,000 & Midwest & School children & 48 & 952 \\
\hline Nimer and cols. & 2002 & 280 & Southeast & School children & 72 & 208 \\
\hline Alves and cols. & 2005 & 141 & Southeast & Infants and preschoolers & 87 & 54 \\
\hline Duarte & 2007 & 964 & Southeast & School children & 15 & 949 \\
\hline Vanacor and cols. & 2008 & 60 & South & Adults & - & 60 \\
\hline Camargo and cols. & 2008 & 1,085 & Southeast & Adults & 85 & 1,000 \\
\hline Marino and cols. & 2009 & 13 & Southeast & Adults & 2 & 11 \\
\hline Rates & 2010 & 428 & Southeast & School children & 19 & 409 \\
\hline Navarro and cols. & 2010 & 145 & Southeast & School children & 5 & 140 \\
\hline Macedo & 2010 & 540 & Southeast & School children & 217 & 323 \\
\hline Milhoransa and cols. & 2010 & 47 & South & Adults & - & 47 \\
\hline Carvalho and cols. & 2012 & 828 & Southeast & School children & 16 & 812 \\
\hline Macedo and cols. & 2012 & 475 & Southeast & Infants and preschoolers & 166 & 309 \\
\hline Almeida & 2013 & 125 & Southeast & Infants & - & 125 \\
\hline Total & - & 22,934 & - & - & 6,638 & 16,296 \\
\hline
\end{tabular}

No: number of subjects evaluated; $\mu \mathrm{g} / \mathrm{L}$ : micrograms per liter. 
Table 3. Urinary lodine Excretion in Brazilian Pregnant Women

\begin{tabular}{|c|c|c|c|c|c|}
\hline \multirow{2}{*}{ Study } & \multirow{2}{*}{ Year } & \multirow{2}{*}{ No of subjects } & \multirow{2}{*}{ Region } & Insufficient intake & Sufficient intake \\
\hline & & & & $<150 \mu \mathrm{g} / \mathrm{L}$ & $\geq 150 \mu \mathrm{g} / \mathrm{L}$ \\
\hline Soares and cols. & 2008 & 147 & South & 29 & 118 \\
\hline Ferreira & 2011 & 191 & Southeast & 109 & 82 \\
\hline Total & - & 338 & - & 138 & 200 \\
\hline
\end{tabular}

No: number of subjects; $\mu \mathrm{g} / \mathrm{L}$ : micrograms per liter.

\begin{tabular}{|c|c|c|c|c|c|c|c|c|}
\hline Study & Events & Total & & st plot & Proportion & $95 \% \mathrm{Cl}$ & W (fixed) & W (random) \\
\hline Esteves, 1997 & 671 & 2165 & & 母 & 0.310 & {$[0.290 ; 0.330]$} & $7.5 \%$ & $14.4 \%$ \\
\hline Nimer and cols., 2002 & 72 & 280 & & 母 & 0.257 & {$[0.207 ; 0.313]$} & $1.1 \%$ & $13.8 \%$ \\
\hline Duarte, 2007 & 15 & 964 & 田: & & 0.016 & {$[0.009 ; 0.026]$} & $46.6 \%$ & $14.5 \%$ \\
\hline Rates, 2010 & 19 & 428 & 女 & & 0.044 & {$[0.027 ; 0.068]$} & $7.5 \%$ & $14.4 \%$ \\
\hline Navarro and cols., 2010 & 5 & 145 & + & $\square$ & 0.034 & {$[0.011 ; 0.079]$} & $3.2 \%$ & $14.3 \%$ \\
\hline Macedo, 2010 & 217 & 540 & & & 0.402 & [0.360; 0.445] & $1.7 \%$ & $14.0 \%$ \\
\hline Carvalho and cols., 2012 & 16 & 828 & 田: & & 0.019 & {$[0.011 ; 0.031]$} & $32.4 \%$ & $14.5 \%$ \\
\hline Fixed effect model & 1015 & 5350 & $\frac{1}{1}$ & & 0.051 & {$[0.045 ; 0.056]$} & $100 \%$ & - \\
\hline Random effects model & & & & & 0.153 & {$[0.069 ; 0.237]$} & - & $100 \%$ \\
\hline
\end{tabular}

Proportion of iodine insufficient intake - region 4

Cl: confidence interval; W: weighted.

Figure 2. Overall meta-analysis of studies from the Southeast.

\begin{tabular}{|c|c|c|c|c|c|c|c|}
\hline Study & Events & Total & & Proportion & $95 \% \mathrm{Cl}$ & W (fixed) & W (random) \\
\hline Duarte, 2007 & 15 & 964 & 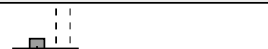 & 0.016 & {$[0.009 ; 0.026]$} & $52.0 \%$ & $36.6 \%$ \\
\hline Rates, 2010 & 19 & 428 & $\begin{array}{lll} & \\
& 1\end{array}$ & 0.044 & {$[0.027 ; 0.068]$} & $8.3 \%$ & $18.8 \%$ \\
\hline Navarro and cols., 2010 & 5 & 145 & 巴 & 0.034 & {$[0.011 ; 0.079]$} & $3.6 \%$ & $10.7 \%$ \\
\hline Carvalho and cols., 2012 & 16 & 828 & 界 & 0.019 & {$[0.011 ; 0.031]$} & $36.1 \%$ & $33.9 \%$ \\
\hline Fixed effect model & 55 & 2365 & $\sum_{i 11}^{11}$ & 0.020 & {$[0.014 ; 0.026]$} & $100 \%$ & - \\
\hline Random effects model & & & $\sum_{11}^{1}$ & 0.024 & {$[0.013 ; 0.035]$} & - & $100 \%$ \\
\hline
\end{tabular}

Cl: confidence interval; W: weighted.

Figure 3. Meta-analysis of studies from the Southeast with IDD prevalence of less than 15.3.

\section{DISCUSSION}

This unprecedented systematic review showed the prevalence of IDD measured in populational studies conducted in Brazil and aimed to answer our main question: What is the overall prevalence of IDD in Brazil?. However, the vast majority of surveys (94, 1\%) were conducted in the South $(4 / 17)$ and Southeast (13/17) regions. Consequently, a comprehensive conclusion about the real IDD prevalence in the country can not be acchieved. While the Southeast region has been recognized as an iodine sufficient area, differences were also detected between states from the same region
(Minas Gerais vs. São Paulo). In São Paulo, there is a rising concern regarding the excessive iodine exposure and predisposition to thyroid autoimmune diseases (Table 2) $(29,33,36,40)$. In contrary, in the state of Minas Gerais, few studies have reported increased IDD prevalence, especially in children and adolescents from low-income populations (Table 2) $(37,38)$. Macedo evaluated 540 children from schools in the municipality of Novo Cruzeiro (Minas Gerais) and observed IDD prevalence of $40 \%$ (38). This might be related to low salt intake, decay of iodine in salt due the storage form and/or expiration date and reduced education level 
(38). Limitations of the number of studies conducted in all regions of Brazil and the possibility of "publication bias" identified in our investigation $\left(\mathrm{I}^{2}=99.5 \%\right.$; $\mathrm{p}$ $<0.0001$ ), made impossible to conduct a meta-analysis for the entire country or particular region (Figure 2). Our quantitative analysis rejected 17 studies because lack of urinary iodine (UI) standardization and similar surveys conducted in the same area.

In our study, only a supplementary central questions (What is the prevalence of IDD in different areas and population groups?) could be partially addressed. The IDD prevalence rate predictied in school children from Southeast region diverged between $24 \%$ (95\% CI, 13$35 \%$ ) and $32 \%$ (95\% CI, 25-39\%), using different analysis methodology (Figure 3). Therefore, we have diagnosed a tremendous heterogeneity available of data. We have demonstrated that the higher rate of $32 \%$ of IDD prevalence, was clearly influenced by two individual studies performed by Esteves (24) and Macedo (38) (Figure 4). Thus, we assumed that the calculated IDD prevalence of $15.3 \%$ (95\% CI, 6-23\%) after biased studies exclusion is the one that could better represents the studies developed in this area, pinpointing to a possible compelling iodine deficiency.

The very few studies $(\mathrm{N}=2)$ executed in North and Northeast regions, did not fit the inclusion criteria for the meta-analysis (Table 1) $(24,35)$. Pontes and Adan (35) assessed the iodine nutritional status and cassava consumption of 180 school children in the city of Cabaceiras/Paraiba (northeast region). The high rate of cassava flour utilization (31.6\%), associated with in elevated rate $(33.3 \%)$ of IDD prevalence in school children. Nonetheless, in this study, the gold standard method for UI evaluation was not used (35). In another survey conducted in north/northeast region, Esteves identified in Bahia, the city of Cocos had low UI level, with median of $44 \mu \mathrm{g} / \mathrm{L},(24)$. Almas, Arraias and Paraná (Tocantins) had median UI of $33 \mu \mathrm{g} / \mathrm{L}$, $34 \mu \mathrm{g} / \mathrm{L}$ and $26 \mu \mathrm{g} / \mathrm{L}$, respectively (24). Therefore, a limitation of the data collected in our review is that the greater number of studies was based only on school survey data, without any enough available information about other population groups. In summary, targeting other essential questions, our review shows that there

\begin{tabular}{|c|c|c|c|c|c|c|c|}
\hline Study & Events & Total & Forest plot & Proportion & $95 \% \mathrm{Cl}$ & W (fixed) & W (random) \\
\hline Esteves, 1997 & 671 & 2165 & 母' & 0.310 & {$[0.290 ; 0.330]$} & $73.2 \%$ & $36.2 \%$ \\
\hline $\begin{array}{l}\text { Nimer and cols., } \\
2002\end{array}$ & 72 & 280 & 母 & 0.257 & {$[0.207 ; 0.313]$} & $10.6 \%$ & $31.0 \%$ \\
\hline Macedo, 2010 & 217 & 540 & 廿 & 0.402 & {$[0.360 ; 0.445]$} & $16.2 \%$ & $32.9 \%$ \\
\hline $\begin{array}{l}\text { Fixed effect } \\
\text { model }\end{array}$ & 960 & 2985 & & 0.319 & {$[0.303 ; 0.336]$} & $100 \%$ & - \\
\hline $\begin{array}{l}\text { Random effects } \\
\text { model }\end{array}$ & & & & 0.324 & [0.254; 0.393] & - & $100 \%$ \\
\hline $\begin{array}{l}\text { Heterogeneity: I-squared } \\
\text { tau-squared }=0.0034, Q\end{array}$ & $\begin{array}{l}\%, \\
9, \mathrm{df}=2,\end{array}$ & 1 & \begin{tabular}{cc}
${ }_{0.3}$ & \multicolumn{1}{c}{} \\
0.35
\end{tabular} & 0.4 & & & \\
\hline
\end{tabular}

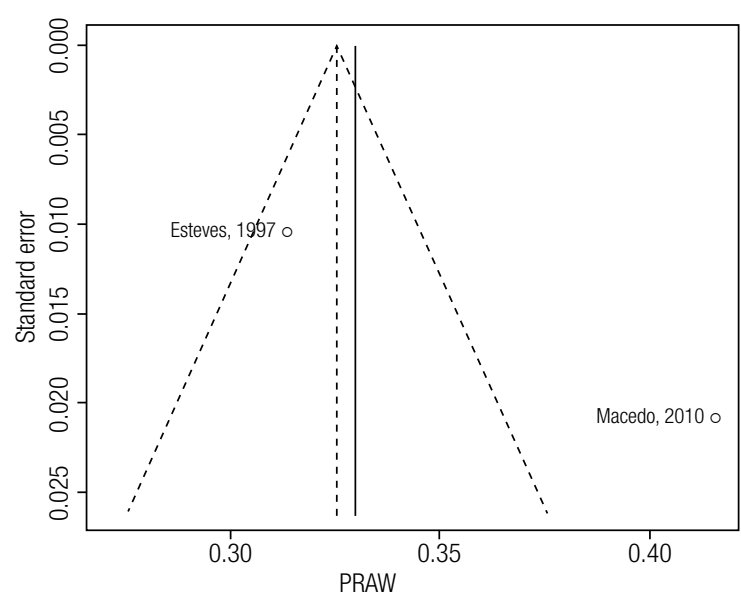

Cl: confidence interval; W: weighted.

Figure 4. Meta-analysis of studies from the Southeast with IDD prevalence of greater than 15.3. 
are not enough studies to profile the population iodine nutrition status in Brazil; and perhaps we might find huge differences related to IDD in individuals of distinct ages, from one region to another, or even in separate areas of the same region. In the manner that the available published data have not considered all country regions and was mostly concentrated in southeast.

The guidelines of the Brazilian Control Program for Iodine Deficiency Disorders (Pro-Iodo), recommended observation in schoolchildren between 6-14 years-old, as the child population is high vulnerable $(5,8)$. Only few studies have analyzed pregnant women $(25,30,43)$. Interesting, Ferreira evaluated 191 pregnant women in Ribeirao Preto, Sao Paulo, and found a very high IDD prevalence $(57 \%)$ and an average UI of $144.4 \mu \mathrm{g} / \mathrm{L}$ (43). It is important to remark that all surveys were conducted when the level of salt iodination were still of 20$40 \mathrm{ppm}$ (ref). Therefore, it is not known if the impact of salt iodization reduction on the health of pregnant and lactating women in Brazil, since this group has a greater need for iodine and previous studies pointed to higher susceptibility for IDD (45). Considering the IDD neurological potential damage during childhood development, the establishment of preventive evaluation for pregnant women and children might be essential (4).

Macedo and cols. (37) when assessing infants and preschoolers in Minas Gerais found a IDD prevalence of $34.4 \%$ (37). Therefore, this group of individuals (children until the fifth year of life) might be also extremely vulnerable for IDD (37). In contrast, Lima and cols. (40) have recently used Inductively Coupled Plasma Mass Spectrometry (ICP-MS) to measure iodine content in breast milk and urine from children during the first six months of life in the state of São Paulo and the data revealed a high average concentration of iodine in breast milk (206 $\mu \mathrm{g} / \mathrm{L})$ and urine $(293 \mu \mathrm{g} / \mathrm{L})(40)$.

Therefore, it seems that only considering the risk of excessive iodine intake, based on studies from southeast region, Brazil has changed the contents of this micronutrient in salt traded domestically to $15-45 \mathrm{ppm}$. However, after adoption of this measure, it would be necessary to monitor the novel iodine nutritional status of the population. Indeed, we hypothesized that the recommended iodination could be modified based on the data about salt intake and UI concentration found for individual area coustolering Brazil each region, especially in a country of continental dimensions with vast differences in socio-demographic, geographic and climate aspects.

The main challenge is to adequate salt iodization and to promote educational and nutritional programs in order to strengthen the IDD or excessive control related to excessive consumption of iodine. Ideally, periodic monitoring of iodine nutritional status of the population in different states would be essential, especially less studied is essential to establishment of the proper individual range of salt iodization. The actual IDD prevalence analysis is complex, because publication bias high heterogeneity between studied. IDD might still be high in some areas but this remained unknown even after this meta-analysis evaluation.

In conclusion, nutritional status of iodine in Brazil has improved over the past few years, in general, in order to control the supply of iodine and reducing the rate of endemic goiter. However, concern about iodine optimal nutrition persists in all regions of the country, especially, after the reduction in the levels of salt iodization (15-45 ppm).

We hypothesized that changes in diet, differences in goitrogens consumption (including cassava), geographical and social demographic characteristics, road construction/commercial negotiation and processed foods availability may explain the coexistence of IDD and excessive intake iodine in different areas of the country. Most studies have been conducted many years ago and the generation of a national program for the analysis of the actual situation iodine in all regions is an urgently needed crucial for establishing the specific salt iodization needed for each region.

Acknowledgments: this study was made possible through financial support from the State of Bahia Research Foundation (Fapesb-PET 0002/2013; Edict 29/2012). We gratefully acknowledge the contribution of Coordination of Improvement of Higher Education (Capes) by awarding scholarship to R.O.C. The researchers who kindly gave papers and/or theses for this meta-analysis.

Disclosure: no potential conflict of interest relevant to this article was reported.

\section{REFERENCES}

1. Delange F, Burgi H, Chen ZP, Dunn JT. World status of monitoring iodine deficiency disorders control programs. Thyroid. 2002;12:915-24.

2. Laurberg P. Thyroid function: thyroid hormones, iodine and the brain-an important concern. Nat Rev Endocrinol. 2009;5:475-6.

3. Laurberg $P$, Jorgensen T, Perrild H, Ovesen L, Knudsen N, Pedersen IB, et al. The Danish investigation on iodine intake and thyroid disease, DanThyr: status and perspectives. Eur J Endocrinol. 2006;155:219-28.

4. Zimmermann MB. The effects of iodine deficiency in pregnancy and infancy. Paediatr Perinat Epidemiol. 2012;26:108-17.

5. Zimmermann MB. The role of iodine in human growth and development. Semin Cell Dev Biol. 2011;22:645-52.

6. Andersson M, Aeberli I, Wust N, Piacenza AM, BucherT, Henschen I, et al. The Swiss iodized salt program provides adequate iodine for school children and pregnant women, but weaning infants not receiving iodine-containing complementary foods as well 
as their mothers are iodine deficient. J Clin Endocrinol Metab. 2010;95:5217-24.

7. Andersson $M$, de Benoist B, Rogers L. Epidemiology of iodine deficiency: Salt iodisation and iodine status. Best Pract Res Clin Endocrinol Metab. 2010;24:1-11.

8. Zimmermann MB. lodine deficiency. Endocr Rev. 2009;30:376-408.

9. Zimmermann MB, Andersson M. Assessment of iodine nutrition in populations: past, present, and future. Nutr Rev 2012; 70:553-70.

10. Laurberg $P$, Cerqueira $C$, Ovesen L, Rasmussen LB, Perrild $H$, Andersen $\mathrm{S}$, et al. lodine intake as a determinant of thyroid disorders in populations. Best Pract Res Clin Endocrinol Metab. 2010;24:13-27.

11. Pearce EN, Andersson M, Zimmermann MB. Global iodine nutrition: where do we stand in 2013? Thyroid. 23:523-8.

12. Brazil. Ministry of Health Department of Health Care DoPC 2007 Technical Manual and Operational Pro-lodine: National Program for Prevention and Control of lodine Deficiency Disorders. Available at: <http://www.unicef.org/brazil/pt/iodo_manual.pdf. Accessed on: June 10, 2013.

13. Brazil. Ministry of Health Department of Health Care DoPC 1974 Federal Law 6,150 of 12/03/1974: Provides for mandatory iodization of salt for human consumption, its control by health authorities and other measures. Available at: <http://www.planalto.gov. br/ccivil_03/leis/L6150.htm. Accessed on: June 18, 2013.

14. Anvisa. ANdVS 2003 Resolução RDC $n^{\circ} 32$, de 25 de fevereiro de 2003, Brasil. Available at: <http://portal.anvisa.gov.br/wps/ wcm/connect/26d5b98048adf9c98d43edfbd8335c80/diario2. pdf?MOD=AJPERES. Accessed on: June 10, 2013.

15. Knobel M, Medeiros-Neto G. Disorders associated to chronic iodine deficiency. Arq Bras Endocrinol Metabol. 2004;48:53-61.

16. Pretell EA, Delange F, Hostalek U, Corigliano S, Barreda L, Higa $\mathrm{AM}$, et al. lodine nutrition improves in Latin America. Thyroid. 2004;14:590-9.

17. Brasil. Agência Nacional de Vigilância Sanitária. Resolução RDC n. 1.477, de 24 de abril de 2013. Dispõe sobre o teor de iodo no sal destinado ao consumo humano e dá outras providências.

18. Moher D, Liberati A, Tetzlaff J, Altman DG. Preferred reporting items for systematic reviews and meta-analyses: the PRISMA statement. Int J Surg. 8:336-41.

19. Welch V, Petticrew M, Tugwell P, Moher D, O'Neill J, Waters E, et al. PRISMA-Equity 2012 extension: reporting guidelines for systematic reviews with a focus on health equity. PLoS Med. 9:e1001333.

20. Wells G, Shea B, O'Connell D, et al. The Newcastle-Ottawa Scale (NOS) for assessing the quality of nonrandomized studies in meta-analyses. Proceedings of the 3rd Symposium on Systematic Reviews. Beyond the basics: improving quality and impact; 2000 July 3-5; Oxford. Oxford, 2000.

21. Vejbjerg $P$, Knudsen N, Perrild H, Laurberg P, Andersen S, Rasmussen LB, et al. Estimation of iodine intake from various urinary iodine measurements in population studies. Thyroid. 2009;19:1281-6.

22. Alves MLD, Maciel RMB, Kunii I, lazigi N. Correlação entre níveis de iodúria eTSH colhido em cordão umbilical de recém-nascidos do Hospital das Clínicas da Faculdade de Medicina de Ribeirão Preto, São Paulo. Arq Bras Endocrinol Metab. 2005;49:516-20.

23. Correa Filho HR, Vieira JB, Silva YS, Coelho GE, Cavalcante Fdos A, Pereira Mda P. Endemic goiter prevalence survey in Brazilian schoolchildren 6 to 14 years old, 1994-1996. Rev Panam Salud Publica. 2002;12:317-26.

24. Esteves RZ. Determinação da excreção urinária de iodo em escolares brasileiros [tese]. São Paulo: Escola Paulista de Medicina, Universidade Federal de São Paulo; 1997.

25. Barca MF, Knobel M,Tomimori E, Cárdia MS, Zugaib M, MedeirosNeto G. Aspectos ultra-sonográficos e prevalência da tireoidite pós-parto em gestantes sem disfunção tireóidea atendidas em hospital público de São Paulo. Arq Bras Endocrinol Metab. 2001:45:180-9.

26. Nimer M, Silva ME, de Oliveira JE. Relationship between iodized salt and urinary iodine excretion in school children, Brazil. Rev Saude Publica. 2002;36:500-4.
27. Saab ARM. Excreção urinária de iodo e prevalência de bócio em escolares de Campo Grande, MS. [tese de mestrado]. Campo Grande: Universidade Federal de Mato Grosso do Sul; 2000.

28. Marino MAS, Martins LC, Esteves RZ, Kasamatsu TS, Maciel RMB. Urinary iodine in patients with auto-immune thyroid disorders in Santo André, SP, is comparable to normal controls and has been steady for the last 10 years. Arq Bras Endocrinol Metab. 2009;53:55-63.

29. Duarte GC. Avaliação ultra-sonográfica da tiróide, excreção urinária de iodo em escolares de 6 a 14 anos e grau de iodação do sal em diferentes regiões do estado de São Paulo [tese]. São Paulo: Faculdade de Medicina, Universidade de São Paulo; 2007.

30. Soares R, Vanacor R, Manica D, Dorneles LB, Resende VL, Bertoluci MC, et al. Thyroid volume is associated with family history of thyroid disease in pregnant women with adequate iodine intake: a cross-sectional study in southern Brazil. J Endocrinol Invest. 2008;31:614-7.

31. Navarro AM, Oliveira LA, de Meirelles CJ, Costa TM. Salt iodination and excessive iodine intake among schoolchildren. Arch Latinoam Nutr. 2010;60:355-9.

32. Camargo RY, Tomimori EK, Neves SC, G S Rubio I, Galrão AL, Knobel M, et al. Thyroid and the environment: exposure to excessive nutritional iodine increases the prevalence of thyroid disorders in Sao Paulo, Brazil. Eur J Endocrinol. 2008;159:293-9.

33. Carvalho AL, Meirelles CJ, Oliveira LA, Costa TM, Navarro AM. Excessive iodine intake in schoolchildren. Eur J Nutr. 2012;51:557-62.

34. Vanacor R, Soares R, Manica D, Furlanetto TW. Urinary iodine in $24 \mathrm{~h}$ is associated with natriuresis and is better reflected by an afternoon sample. Ann Nutr Metab. 2008;53(1):43-9.

35. Pontes AA, Adan LFF. Interference of iodine and goitrogenic foods in the appearance and evolution of thyroid diseases. Rev Bras Ciênc Saúde. 2006;10:81-6.

36. Alves ML, Duarte GC, Navarro AM, Tomimori EK. Ultrasonographic evaluation of the thyroid, determination of ioduria and iodine concentration in kitchen salt used by schoolchildren in Ribeirao Preto, Sao Paulo, Brazil. Arq Bras Endocrinol Metabol. 2010:54:813-8.

37. Macedo MS, Bonomo AT, Silva E, Silva CAM, Sakurai ME, Carneiro $E$, et al. lodine deficiency and associated factors in infants and preschool children in an urban community in the semiarid region of Minas Gerais State, Brazil, 2008. Cad Saúde Pública. 2012;28:346-56

38. Macedo MS. Status nutricional de iodo e seus determinantes em crianças e adolescentes de um município do Semiárido de Minas Gerais, 2008. [Dissertação de mestrado]. Belo Horizonte: Faculdade de Medicina, Universidade Federal de Minas Gerais; 2010.

39. Milhoransa P, Vanacor R, Furlanetto TW. Intra- and interindividual iodine excretion in 24 hours in individuals in southern Brazil: a cross-sectional study. Ann Nutr Metab. 2010;57(3-4):260-4.

40. de Lima LF, Barbosa Junior F, Navarro AM. Excess iodinuria in infants and its relation to the iodine in maternal milk. JTrace Elem Med Biol. 2013:27:221-5.

41. Rates SPM. Avaliação do estado nutricional de iodo em escolares adolescentes de 10 a 19 anos de escolas públicas do Município de Vespasiano, MG. [Dissertação de mestrado]. Belo Horizonte: Faculdade de Medicina, Universidade Federal de Minas Gerais; 2010.

42. Almeida RF. Normatização da volumetria sonográfica da glândula tireoide no período neonatal [Tese de Doutorado]. São Paulo: Faculdade de Ciências Médicas da Santa Casa de São Paulo; 2013.

43. Ferreira SMS. Avaliação da importância da triagem do hipotireoidismo e da suficiência iódica em gestantes de Ribeirão Preto. [Dissertação de mestrado]. Ribeirão Preto: Faculdade de Medicina de Ribeirão Preto, Universidade de São Paulo; 2011.

44. Rossi AC, Tomimori E, Camargo R, Medeiros-Neto G. Searching for iodine deficiency disorders in schoolchildren from Brazil: the Thyromobil project. Thyroid. 2001;11:661-3.

45. World Health Organization. United Nations Childrens Fund. International Council for the Control of lodine Deficiency Disorders. Assessment of iodine deficiency disorders and monitoring their elimination: a guide for programme managers. 3rd ed. Geneva, 2007. 